\title{
Finding Socio-Cultural Strategy to Develop Gender Equality: A Comparative Study of the Gangnam Station Murder Case and the Delhi Bus Gang Rape Case
}

\author{
Goeun Kwak
}

\begin{abstract}
Both Korea and India are quite similar in that they demand women's chastity, male-dominated patriarchal consciousness is prevalent, and the social atmosphere in which the victims of sexual crimes are responsible. However, the violent crimes against women that have made a great impact on these two societies ('Gangnam station murder' in 2016 and 'Delhi bus gang rape' in 2012) occurred, but the political impacts of the two cases on each society were different.

In both non-Western democracies, where women's oppressive culture remained strong under patriarchal values, the two events were common in that they became turning points that exploded the perceptions of sex offenses. However, the attitudes of the media, the views of men, and the reactions of the two nations showed differences. By analyzing the difference between the two cases, we will explore the socio-cultural strategy to develop gender equality.
\end{abstract}

Keywords - misogyny, Gangnam Station Murder, Delhi Bus Gang Rape, gender equality politics

\section{INTRODUCTION}

Between Korean and Indian society are there many differences originated in history, race, religion and culture. But both the societies are patriarchal and unequal in gender, and recently have suffered the big incidents(Gangnam station murder in Korea and Delhi bus gang rape in India), which have had major impact on the gender equality politics of these two oppressive countries. The two events appear to be quite similar in terms of their social background and progress. However, compared to the Delhi case, extended the perception of gender equality to society as a whole and made institutional change, the Gangnam Station case was not enough to share the awareness of misogyny crime and to bring about institutional change.

It is not easy to compare the two societies with many differences in many ways. However, both the two societies are common in the patriarchy and gender inequality and differences and suffer the same kind of cultural lag with rapid modernization. In such a similar condition, however, the two societies responded differently facing the similar cases. In order to explain the different consequences, it needs to focus on the contextual difference and discern the critical point.

\footnotetext{
Goeun Kwak/ Sogang University, Republic of Korea, goneegonee@gmail.com
}

Just as Geertz discovered the nature of Balinese people and the attribute of their society in Balinese cock fight, we can reach the general facts through special cases. It is to discover the meaning of social phenomenon by exploring the meaning and social context of individual society rather than law [1].

The two cases were selected to emphasize the implications of this particularity. This thesis is an extension of the unconscious comparisons of researchers based on the unconscious and intrinsic knowledge gained from the first encounter of the event. Through this, it aims to understand more intrinsic and analytical phenomena. In addition, it is expected to help understand the subjectivity of each actors in different social contexts and explore why the outcomes were different.

\section{TWO CASES - TWO SIMILAR TURNING POINTS}

\section{A. In case of Korea - Gangnam Station Murder in 2016}

Korea is one of the countries where women's social activities are free and safe, and it seems to be given much better social conditions than India. But Korea still has strong roots in patriarchy and there is a clear inequality. It is also one of the countries where sex crimes are constant, pass the responsibility to the victim, and have serious side effects. Obviously, our society's awareness of sexual crimes has changed over the past several decades, and there are obviously improvements. Nevertheless, still many sex crime cases are repeated every day. Despite the seriousness of sexual crime in Korean society, it was not apparent on the surface due to the responsibility to women and the tolerance of male sexuality

The event on May 17, 2016 was a turning point in the Korean society, especially the change in the awareness of gender equality among Korean women. The assailant was a 34-year-old male, hiding in the toilet near Gangnam Station and waiting for victims. While six men entered the toilet and waited for a while, he murdered a 23-year-old female college student who came in for the seventh time. And after being arrested, he said, "I have been ignored by women and committed a crime, and I do not know the victim."

The murder occurred constantly before and after that. However, the case of Gangnam Station is known, and many women, mainly on-line, perceived the incident as a murder based on misogyny. The victim, who had nothing to do with the 
perpetrator, perceived it as just an incident because she was a woman. There was a memorial service centered around women who were deeply sympathized and shocked, and in front of Gangnam Station Exit 10, thousands of Post-it memorials of victims were attached. "I was just lucky and survived." "A woman was murdered because we neglected misogyny in this society." Many women criticized the women's abhorrence of Korean society by feeling responsible and bond to the victim's death.

The debate arose every day. Many men expressed displeasure that they were treated as potential victims, and they defined the incident as motiveless crime by a mentally ill person. There has also been a rush of critics accusing radical women activists of using the victims' deaths. The debate became furious, but the women marched in tribute without stopping. Many women have come to recognize that 'misogyny' lies behind the case.

B. In case of India - Delhi Bus Gang Rape in 2012

On December 16, 2012, a 23-year-old female college student in Delhi was brutally raped in the bus. The horrors of the incident have shocked India all over the world and spread to the world all over the world.

Rape was frequent in Indian society. However, as in our society, Indian society was also strongly stigmatized and prejudiced against the victims. Most of the victims were not able to report because of social prejudice that was wet with the sense of innocence, and the police did not actively deal with sex crimes. But this case was different. The people of India were angry. There was national resistance and protests in the city of New Delhi, where protests were held in anger every day. Indian society was surprised that this happened in the city of Delhi. There was a consensus that 'no more should be done.' The protests spread to other areas, and the police did not stop their oppression.

Anger and shock soon turned to pressure on politicians. For the first time in the Indian society, violence against women has become a political issue. A special committee was formed and an amendment to the criminal law was submitted one month later. Four months after the incident, the bill passed, and many related laws were pending, which was very unusual considering the slow pace of Indian society's pace. Sex crime, which I consider to be a chronic social problem, was not a serious problem on the one hand, but it turned out to be a huge issue that would change the slow administrative process that was a chronic problem in India.

\section{STAGNANT SOCIETY AND CHANGING WOMEN}

Over the past several decades, the economy has developed rapidly. Third worlds, such as India and Korea, have developed rapidly in the decades since the economic achievements of two hundred years of Western society. In particular, India has radically changed and grew after the economic opening of the 1990s. With the development of the Indian economy and the opportunity for young women to be educated and employed, they naturally expected that hospitality in the Indian society would be different regardless of the class [2].

According to Indian law, which does not disclose the victim's real name (Later, her parents disclosed her blindness, hoping she would be a hope for Indian women and victims), the press called her Nirbhaya (fearless in Hindi). Nirbhaya was exactly that changing Indian typical woman. An educated woman who hopes to do anything despite being a woman

However, the perception of the vast majority of Indian males represented by the perpetrators was different. They did not think of women as equal to men, and they accepted the rise of women as a challenge to men. They thought of violence against women as men's rights. One of the perpetrators, Mukesh Singh, was an act to give a lesson about the girl who went out late at night and blamed the victim that she should not have resisted while she was being raped [3].

It was not a problem of Mukesh Singh alone. Women's anger broke out in the atmosphere of a society where the responsibility of sexual violence was transferred to women. It may be difficult to give a clear reason. But as the dam collapsed, things were piled up. It was like an explosion of long-term anger [4]. The new and modern India and the old and backward India became the main frames of the conflict [5].

Korea was not much different. As the economy developed and women's social advancements increased, the men of the relative poor felt deprivation. They thought that (In the past they were not their competitors) women had taken away everything they should have enjoyed, and turned the cause of all inequalities to women. Even though most victims of violent crime are women(87.2\% in 2014, Crime analysis statistics by the National Police Agency) and they are experiencing economic inequality(Ranked 115 out of 145 countries in Global Gender Gap Report of the World Economic Forum and Korea has biggest gender wage gap among OECD nations, also the worst country for working women in Glass-ceiling index of The Economist[6]) they think that "the best living generation in Korean society is women in their 20s and 30s" [7].

Despite the similarity of these backgrounds, however, the two events produced different results. The attitudes of the media, the views of men, and the reactions of the nations in the two countries showed differences. India has achieved much of the performance of the movement through institutional reforms, along with changes in social awareness, but in Korea, despite many controversies, it has not been recognized as a misogyny or gender inequality. Of course, the two countries are fundamentally different countries. However, it is necessary to point out the context in which certain independent variables have resulted in differences in results. Because understanding the differences in context is related to creating social conditions for the development of gender equality consciousness.

\section{MEN'S PARTICIPATION - THE DIFFERENCE}

The biggest difference was in the size of the protesters and their members. In India, as well as women, many men participated in the demonstrations. This was a reaction that was not easy to imagine at first glance, considering the maladjusted consciousness of males in Indian society. Why did Indian men get angry like women.

Pamela Philipose[8] says the brutality of the incident is the first reason that so many people have protested and become international issues. But a second important reason for crowds of people spontaneously converging to the sites of protests was a sense of solidarity created by gender activism. The public 
became aware of the need to be solidarity, influence, and resistance to sexual violence together. And the active participation of a large number of men in the process of such counter mobilization.

So what was the case of Gangnam Station Murder? Because there was no brutality and social solidarity, only women recognized the case (not a crime of mental illness, but rather a sexual offense based on misogyny and gender equality) properly and were angry?

Of course, there were brutality and social solidity in Gangnam Station. But it only affected women. Because the case of Gangnam Station was not a rape case but a murder case.

Most men perceive rape to be sexually explicit, but not murder. It is an accidental crime by a mentally ill person, but the victim was just a woman. In other words, the victim who was caught without any unspecified majority was female, and was not perceived as sex crime. They are also angry with the mental patient who is the compassionate and perpetrator of the murder victim, but that is clearly another story. Because of this difference in perception of the events, most men were unable to form consensus with angry women.

In such a situation, when the angry women began to talk about misogyny, men felt rather repulsive. They thought, "I am a man and I can be murdered by a mentally ill person, but why do you think that only women are victims?" They sympathize with the memorial of the victim and the anger of the criminal, but it is close to the sadness of the death of a young woman who has become a victim of motiveless murder.

Opinions of experts are mixed. There is no credibility in the statement of a mental patient who cannot normally make a decision (Soo-joung Lee, professor of crime psychology at Kyonggi University)[9]. But the question is whether the controversy of misogyny that did not exist in previous crimes has happened after this incident. In order to know why these reactions occurred, it is necessary to understand the background and context of social change. It is because the understanding of the context explains the specificity of why this event differs from the events of the past.

Sung-soo Hong, a professor at Sookmyung Women's University College of Law, said, "It is not unreasonable to see it as a misogyny case because it is an event that targets 'any woman' rather than just 'anyone' [10] "

Cheon-seok Seo, a psychiatrist, said, "Symptoms of psychosis are in a social context. The problem is that he committed a crime by saying that 'women ignored me.' This word has a social context called 'misogyny'. In past authoritarian dictatorships, many schizophrenic patients suffered from the illusion that the Central Intelligence Agency follows and intercepts me. The CIA (of America) became a theme of hallucination in the late 1980s, and Samsung in the 2000s. As such it should be noted that the current emerging 'misogyny'. If misogyny is developing into a symptom of a mental illness, it must be seriously acknowledged. And structural reform and change of consciousness should be pursued so that such consciousness does not appear in society as a whole.[10] "

Na-young Lee, a professor in the Department of Sociology at Chung-Ang University, said, "I do not see it as a direct hate crime, but it seems to be seen as a crime caused by the abhorrence of unconsciousness." "It is more important how people accept this case than whether one individual murdered women with a sense of repulsion." It means there is necessary to look at the context of why the public accepts this case as misogyny crime and issues it, such as memorial made out of post-it notes and many people respond to the criticism of misogyny in this society.

In this context, we can deduce how women feel solidarity and empathize with the case. Women felt nested fear with motiveless crime and misogyny crime, which made women feel brutal. Also, the sense of solidarity derived from such dual fear was different from the broad but shallow fear of motiveless crime. The situation in which one of the 'women' was subjected to a crime was a much more specific fear. Failure to understand women's fear and anxiety comes from their inability to understand women's perspectives. In the end, this is a question of whether or not we see it from the viewpoints of those who have power and those who have no power [11].

If so, do Indian men have the same sense of solidarity with women? Even if it was clearly a sexual offense, cruel, protest continued and affected, men are usually not the main victims of rape. It is not easy for common men to sympathize with victims in a severe Indian society. If the anger of the oppressed women has been blown away, there is a question of where the anger of many men who were protesting together came from.

The South Asia Analysis Group's Dr.Krishnamachari explained that the protest was an expression of middle class anger arising from the collapse of the social contract between them and the liberal state. He says it is a result of the chaos caused by the short-term rapid growth over the past two decades. There has been a growing distrust of the government in India, where politicians are suffering from chronic corruption, unemployment and the gap between rich and poor. It appeared as anger when an ordinary woman was caught in an early evening in the heart of the capital Delhi of India [12].

\section{AFTER THE TURNING POINT - DIFFERENCES IN RESULTS}

The demonstrations continued after Nirbhaya's death from the day following the incident. When the police suppressed the demonstrators, the demonstrators' behavior became more violent. The number of protesters has continued to increase and has spread to other parts of the country, including Delhi, as well as Calcutta and Mumbai. It was not a past demonstration restricted to caste, religion, region, or political party. It was another qualitatively different protest [13].

Of course, the impact of the incident on society was not everything. The government led by the INC (Indian National Congress) was declining, and it was dangerous to ignore the demands of angry protesters. If they were conscious of the next election, they had to take political action. Many politicians, including Sonia Gandhi, leader of INC, demanded fair trials and legal amendments. Prime Minister Manmohan Singh also expressed deep condolences. Some politicians, such as Abhijit Mukherjee, denounced the demonstrators or criticized Nirbhaya's conduct, but they had to apologize for their improper words. The massive protests have acted as a political pressure.

The Indian government's response, which was so unusual, was also drawn from the pressure. Overall, it was a very unusual 
case for India to quick all the administrative tasks and to indict a rape case to the court immediately. The INC that was preparing for the election the following year would have had a political burden to meet the demands of a changing society. At this point we cannot help comparing with the lukewarm attitude of Korean politics at the time of the Gangnam Station incident. If there were a "larger scale" resistance in Korea, regardless of gender, region or class, Korean political parties would also have been under political pressure.

On December 22, The Justice Verma Committee was appointed by the central government to submit to a report within 30 days to criminal law to sternly deal with sexual assault cases. The Justice Verma Committee report was submitted after 29 days, after considering 80,000 suggestions received during the period. On 1 January 2013, a task force headed by the Union Home Secretary was established to look into women's safety issues in Delhi and review the functioning of the city police force on a regular basis. On 22 December 2015, Rajya Sabha passed the Juvenile Justice Bill, which proposed that the accused who are above 16 years of age will be treated as an adult in the court of law [14]. It was not merely a revision of the criminal law, but a desire for change in Indian society [13].

The system that has changed since the actual event has a formally significant meaning. Stalking and other crimes that had not been recognized as crimes have become to be legally punished, and major reforms have been made inside the police. It has become possible to change the system entirely so that the person in charge of the case cannot ignore such incidents, and to report to the police a relatively minor incident such as sexual harassment. But more importantly, it was a change that women themselves made for themselves.

This change does not represent the vast majority of men in India. There was a debate on equity in the fast track court, which has been established to deal with sexual crimes. There is also a criticism that many criminals commit political crimes based on public opinion rather than punishment even if they commit crimes similar to the crime. The important thing is that they realized the value of equality which was stated in the Constitution but was not actually followed. One big event cannot completely change society as a whole. But the explosive changes in patriarchal and oppressive Indian society are more meaningful because of the specificity of such contexts. It will be recorded as a political turning point for developing gender equality awareness in India.

The criminal in the case of Gangnam Station was sentenced to 30 years' imprisonment. But, the case was officially recorded as "motiveless murder", not a murder based on misogyny. Political circles have taken a vague attitude toward the substance of the case and have not properly dealt with it, though they lamented the victim.

However, Korean society (even though the opinion diverged) came up to the misogyny and understood its meaning. Memories of the victim and anger left a strong bond to the women. Young women activists appeared and made everyone who shares the memory as activist.

The perception of Korean society stays in the confrontation between those who see it as a murder by misogyny and those who perceive it as a "motiveless murder" caused by a mentally ill person. Future change should go one step further from that point.

The start of change could be triggered on either side. But the direction of the change should be toward all human beings. There needs to be greater solidarity in order to create political pressure to bring about institutional change and to change the perception of the society as a whole. This is not a problem only for Korea or India. In the western world, which is thought to be a relatively gender-equal society, there is still misogyny and gender inequality. Like the SlutWalk[15] in Canada, special efforts need to match the context of each society.

\section{REFERENCES}

[1] C. Geertz, "The interpretation of cultures," Ch.1, Ch.15. Basic Books, 1973

[2] Interview of Maria Misra (Historian, Oxford University, Keble College) from documentary film "India's Daughter" by Leslee Udwin, 2015

[3] Interview from film "India's Daughter"

[4] Interview of Kavita Krishnan (Secretary of the All India Progressive Women's Association ) from documentary film "India's Daughter" by Leslee Udwin, 2015

[5] P. Roychowdhury, "The Delhi Gang Rape": The Making of International

[6] http://www.koreaherald.com/view.php?ud=20160828000266

[7] Korea Women's Development Institute, 2015

[8] P. Philipose, "Anti GVB Feminist Activism in India: New Breakthroughs, New Challenge" Lecture in EGEP open seminar, 2016

[9] http://www.ohmynews.com/NWS_Web/View/at_pg.aspx?CNTN_CD=

[10] http://news.chosun.com/site/data/html_dir/2016/05/19/2016051901826. html

[11] S. Choi, "Distortion of Women's Perceptions Pervasive in Korean Society Kangnam Station Murder Case" Korean Women's Theology, 2016

[12] Krishnamachari ,"Understanding issues raised by the Delhi gang-rape case". South Asia Analysis Group Post. 132013.

[13] Interview of Leila Seth from documentary film "India's Daughter" by Leslee Udwin, 2015

[14] 2012 Delhi Gang Rape, Wikipedia

[15] SlutWalk is a protest march to urge an end to the culture of rape. Specifically, participants object to the perception that women's clothing causes rape. The protest began in Toronto, Canada in 2011 after Toronto police suggested that "women should not be dressed like prostitutes" as a precaution against sexual violence. 